\title{
Co po postmodernizmie? Derrida i nietożsamość
}

\author{
Roman Chymkowski \\ (Uniwersytet Warszawski, Instytut Kultury Polskiej)
}

\section{Postmodernizm postkolonialny}

Jedno z ogólnych zdań, jakimi można określić miejsce, z którego współczesna humanistyka formułuje pytania, głosi, że żyjemy po końcu pytań o koniec. Z nieco już zakurzonych i pożółkłych książek dobiegają nas pytania o to, czy filozofia się skończyła, czy skończyła się humanistyka albo czy kres swój osiągnął nietożsamy z nią humanizm. Jakkolwiek sformułowanie „koniec filozofii” w drugiej połowie XX wieku zawdzięczamy - wprost lub niebezpośrednio - Martinowi Heideggerowi ${ }^{1}$, w praktyce było i niekiedy wciąż jest używane w rozmaitych znaczeniach. Wśród wielu sformułowanych pół wieku temu koncepcji wskazujących na koniec filozofii można wyodrębnić dwa wzajemnie przenikające się nurty. Pierwszy z nich za motto mógłby mieć ostatnią z Tez o Feuerbachu - nie tylko ze względu na Marksowskie i marksistowskie inspiracje, ale także $z$ uwagi na treść postulatywną: oto nadszedł czas, by od teorii przejść do praktyki, od abstrakcyjnej spekulacji do politycznego czynu. Drugi historyczny nurt refleksji nad końcem filozofii można określić jako p o s t e u r o p o c e n t r y c z n y. Chodzi tu o coś więcej niż stwierdzenie faktu, że gdzie indziej żyją ludzie, którzy myślą

Por. M. Heidegger, Koniec filozofii i zadanie myślenia, przeł. K. Michalski, w: Drogi współczesnej filozofii, wybór i wstęp: M. Siemek, Czytelnik, Warszawa 1978. Tekst ten pierwotnie ukazał się w przekładzie francuskim, por. M. Heidegger, La fin de la philosophie et la tâche de la pensée, przeł. J. Beaufret, F. Fédier, w: Kierkegaard vivant: colloque organisé par l'Unesco à Paris du 21 au 23 avril 1964, Gallimard, Paris 1966. 
inaczej niż my, a mianowicie, że nasz sposób myślenia jest swoiście pojętą ideologią uprawomocniającą polityczną dominację Zachodu nad resztą świata.

Wiele diagnoz dotyczących końca filozofii sformułowano na początku lat sześćdziesiątych XX wieku i nie było sprawą przypadku, że ten szeroko zakrojony proces rozliczenia filozofii zbiegł się w czasie $\mathrm{z}$ rozpadem europejskiego systemu kolonialnego. Posteuropocentryczny i postkolonialny ton krytyki tradycji intelektualnej Zachodu prowadzonej przez francuskich intelektualistów na początku drugiej połowy XX wieku był genetycznie związany z doświadczeniem dekolonizacji, zwłaszcza zaś toczącej się w latach 1954-1962 wojny, wskutek której Algieria ogłosiła niepodległość, zadając ostateczny cios panowaniu Francji w tej części świata. Wojna ta była pierwszorzędnie ważnym punktem odniesienia dla co najmniej dwóch pokoleń francuskich intelektualistów ${ }^{2}$, także tych, których $z$ perspektywy czasu kojarzymy jako fundatorów perspektywy postmodernistycznej ${ }^{3}$. We wprowadzeniu do wyboru pism Sartre'a poświęconych kolonializmowi Azzedine Haddour formułuje sugestywną myśl o tym, że biorąc pod uwagę biografie intelektualistów, którzy odcisnęli największe piętno na humanistyce drugiej połowy XX wieku, „debata wokół problemu nowoczesności i ponowoczesności mniej ma wspólnego z decentralizacją Kartezjańskiego podmiotu niż z realiami politycznymi postkolonialnej Francji"4. Z tego punktu widzenia postkolonialny ton formułowanych przez postmodernistów diagnoz końca nie nazywa tego, co marginalne, lecz odsyła do doświadczenia o fundamentalnym znaczeniu, rdzenia naszego współczesnego sposobu widzenia świata, naszego sposobu bycia w nim.

Wyczuleni na aktualne problemy społeczne czy polityczne łatwo zapominamy o okolicznościach, które w niezbyt odległej przeszłości doprowadziły do sformułowania łączonych z tzw. postmodernizmem diagnoz końca. Amnezja prowadzi do uproszczeń - pisząc z pozycji po końcu postmodernizmu Andrzej Leder stwierdza, że ten nurt myślenia, w szczególności analizy Jacques'a Derridy, doprowadziły nas „do jakiejś ściany, albo raczej na granicę nie-istnienia, nie-istotności - wielkiego morza pustki, na którym mienią się refleksy reflek-

Por. J.D. Le Sueur, Uncivil War. Intellectuals and Identity Politics during the Decolonization of Algeria, wstęp: P. Bourdieu, University of Nebraska Press, Lincoln-London 2005.

3 Por. J.-F. Lyotard, La guerre des Algériens. Écrits 1956-1963, opr. i wstęp: M. Ramdani, Galilée, Paris 1989.

4 A. Haddour, Introduction: Remembering Sartre, w: J.-P. Sartre, Colonialism and Neocolonialism, przeł. A. Haddour, S. Brewer, T. McWilliams, Routledge, London-New York 2001, s. 14. 
sów znaczeń?”'. Postmodernizmowi Leder przeciwstawia „brutalność realnego - które ujawniło się gdzieś pomiędzy wydarzeniem płonących wież World Trade Center a upadkiem Lehman Brothers, z rzezią następującą po arabskiej wiośnie”. Nie podejmując kwestii wieloznaczności terminu „postmodernizm” i zasadności określania tą samą nazwą myśli Derridy, Foucaulta i Lyotarda, chcę wskazać kilka najważniejszych problemów związanych z recepcją twórczości autora O gramatologii, ponieważ to właśnie w tym przypadku szczególnie wyraźnie widać konsekwencje lektury ahistorycznej, separującej myśl od doświadczenia.

Oczywiście ten nurt recepcji dorobku Derridy jest bardzo popularny. Zapewne nie jest to bez związku z tym, że pierwsza fala recepcji jego twórczości miała miejsce na gruncie literaturoznawstwa. W tej optyce Derrida jest przywoływany niemal wyłącznie jako autor koncepcji dekonstrukcji. Literaturoznawcze przechwycenie filozofii Derridy, jakkolwiek - co można stwierdzić ex post - bardzo płodne poznawczo, ma m.in. tę konsekwencję, że odsuwa na dalszy plan albo wręcz pomija jej wymiar polityczny. $Z$ drugiej strony konsensus dotyczący tekstocentrycznego charakteru myśli Derridy wyjaśnia zarzuty formułowane przez autorów oczekujących od działalności intelektualnej tak czy inaczej rozumianego krytycznego zaangażowania w problemy „żywych ludzi”. Przykładowo - kolega Derridy z czasów szkolnych, Pierre Bourdieu, twierdzi, że zamykająca się w obrębie czytanego tekstu dekonstrukcja prowadzi do szczególnego rodzaju filozoficznego nihilizmu? ${ }^{7}$ W Polsce podobny wniosek sformułował, wychodząc $z$ innych przesłanek, Włodzimierz Lorenc; pisze on, że „dekonstrukcja zdejmuje z nas wszelką odpowiedzialność"s. W tym ujęciu Derrida podważający założenia europejskiego humanizmu „traci [...] zainteresowanie dla świata i nie chce rozwiązywać jego problemów ani w sposób teoretyczny, ani praktyczny. [...] W wyniku dekonstrukcji nie otrzymujemy praktycznie niczego w zamian za idee, na których opierało się dotąd nasze życie" ".

W popularnych wykładniach myśli Derridy, sytuujących ją zdecydowanie po stronie tekstocentryzmu, jedną z najczęściej przywoływanych sentencji jest

$5 \quad$ A. Leder, Byt kiedyś postmodernizm... Sześć esejów o schyłku XX stulecia, Wydawnictwo IFiS PAN, Warszawa 2018, s. 9.

6 Tamże, s. 9.

7 Por. P. Bourdieu, Dystynkcja. Społeczna krytyka władzy sądzenia, przeł. P. Biłos, Wydawnictwo Naukowe Scholar, Warszawa 2005, s. 613.

8 W. Lorenc, Hegel i Derrida. Filozofia w wersji radykalnej, Instytut Filozofii UW, Warszawa 1994, s. 232.

9 Tamże, s. 232. 
występujące w charakterze oczywistego dowodu krótkie, wyrwane z kontekstu zdanie z O gramatologii: „Nie istnieje poza-tekst”"10 [il n'y a pas de hors-texte]. Wypowiedź tę pojmowano jako postulat, by treści czytanego tekstu nie odnosić do rzeczywistości pozatekstowej; czasem zaśw ten sposób, że cały świat jest tekstem, tzn. jest ustrukturyzowany jak tekst i jak tekst powinien być rozumiany. Tę drugą interpretację znajdujemy m.in. w książce Agaty Bielik-Robson. Sytuująca myśl Derridy w kręgu „kryptoteologii kabalistycznej” autorka podsumowuje ten wątek konstatacją, że świat ,jest przekładem źródła”"11.

Zdanie Derridy, które zrobiło taką karierę, znajduje się w tym miejscu jego rozprawy, w którym odnosi się on do Rousseau, i - co trzeba podkreślić - nie ma charakteru twierdzenia ontologicznego, lecz jest uwagą metodologiczną. Już w następnym zdaniu Derrida stwierdza, że „dostęp do [...] tak zwanego 'rzeczywistego' istnienia mamy jedynie w tekście i nie mamy żadnego sposobu, by postąpić inaczej, ani żadnego prawa, by pominąć to ograniczenie"12. Skądinąd lektura zwłaszcza tych partii O gramatologii, które dotyczą Rousseau, nie tylko nie uzasadnia tezy o ontologicznym tekstocentryzmie Derridy, ale także wydaje się prowadzić do wniosku o podstawowej roli doświadczenia. Prawdą jest, że w przypadku Rousseau dostęp do jego życia mamy wyłącznie za pośrednictwem źródeł pisanych i w tym sensie „nie istnieje poza-tekst”, ale lektura jego pism filozoficznych wraz z Wyznaniami dowodzi, że tezy metafizyczne, w tym sądy na temat norm etycznych, nie wytrzymują konfrontacji z doświadczeniem. Derrida omawia ten problem na przykładzie postawy Rousseau wobec autoerotyzmu. Bezwzględne potępienie tej praktyki w Emilu wchodzi w kolizję z Wyznaniami, w których Rousseau pisze o fetyszyzmie i masturbacji, na własnym przykładzie zauważając wręcz, że w ten sposób można osiągnąć większe spełnienie niż w kontakcie z kobietami ${ }^{13}$.

$\mathrm{Z}$ tego punktu widzenia doświadczenie wymykające się dualizmom jest antymetafizyczne ${ }^{14}$. Dzięki niemu, dzięki jego niszczycielskiej sile, lepiej widzimy roszczenia filozofii do uniwersalności oraz opresyjny charakter tych roszczeń. Uważna lektura wczesnych pism Derridy pokazuje, że refleksja nad doświadcze-

\footnotetext{
10 J. Derrida, O gramatologii, przeł. B. Banasiak, Wydawnictwo KR, Warszawa 1999, s. 217.

11 A. Bielik-Robson, „Na pustyni”. Kryptoteologie późnej nowoczesności, Universitas, Kraków 2008, s. 122. 
niem jest stale obecna właściwie od początku jego twórczości. Komentując mesjanistyczną eschatologię Emmanuela Lévinasa, pisze: „Chce, aby ją rozumiano w odniesieniu do samego doświadczenia. Samego doświadczenia i do tego, co w tym doświadczeniu najbardziej nieredukowalne: droga i wyjście ku innemu; innemu, który sam ujmowany jest przez to, co w nim nieredukowalnie inne: innemu człowiekowi"15.

\section{Algieria, czyli nietożsamość}

Mówiąc, a częściej jednak pisząc o tym, czym jest pismo, fallocentryzm i dekonstrukcja, Derrida nie tylko odnosi się do kultury francuskiej lub historii Europy, ale także wskazuje na swoje doświadczenia dzieciństwa spędzonego na południowym brzegu Morza Śródziemnego, w Algierii. W filmie dokumentalnym pt. D’ailleurs, Derrida ${ }^{16}$ widzimy go jako niemal siedemdziesięcioletniego mężczyznę spacerującego po przedmieściach rodzinnego Algieru, kiedy zza kadru dobiegają słowa o myśli, która rodzi się podczas przekraczania granicy oddzielającej od tego, co gdzie indziej. Owo „gdzie indziej”, nawet jeśli jest bardzo blisko, także wewnątrz ,ja”, w sercu, w ciele, zawsze znajduje się poza pewną granicą.

O związku myśli autora $O$ gramatologii z jego z algierskim pochodzeniem obszernie pisze m.in. Mustapha Chérif ${ }^{17}$. Wiele informacji na ten temat można znaleźć w jego biografiach, zwłaszcza w książce Jasona Powella ${ }^{18}$. Sam Derrida $\mathrm{w}$ publikowanych pracach odnosił się do swojego doświadczenia biograficznego w sposób raczej zdawkowy, przywołując je w charakterze przykładu albo tła historycznego. $Z$ tego punktu widzenia na szczególną uwagę zasługuje wydany w 1996 roku tekst pt. Jednojęzyczność innego, czyli proteza oryginalna ${ }^{19}$. Jak zwykle u tego autora mamy tu do czynienia $\mathrm{z}$ grą konwencją gatunkową - wypowiedź ta została skomponowana częściowo $\mathrm{w}$ formie dialogu z Abdelkébirem Khatibim, autorem m.in. La Mémoire tatouée: autobiographie d'un décolonisé20.

15 J. Derrida, Przemoc i metafizyka, w: tegoż, Pismo i różnica, przeł. K. Kłosiński, KR, Warszawa 2004, s. 141.

16 Por. D’ailleurs, Derrida, reż. S. Fathy, 1999.

17 Por. M. Chérif, L'Islam et l'Occident. Rencontre avec Jacques Derrida, Odile Jacob, Paris 2006.

18 J. Powell, Jacques Derrida: A Biography, Continuum, London-New York 2006.

19 Por. J. Derrida, Jednojęzyczność innego, czyli proteza oryginalna, przeł. A. Siemek, „Literatura na Świecie" 1998, nr 11-12 (328-329).

20 Por. A. Khatibi, La Mémoire tatouée: autobiographie d’un décolonisé, Denoël, Paris 1982. 
W tekście tym Derrida konsekwentnie pisze o sobie jako „Franko-maghrebińczyku”, wskazując, że może „się uważać jednocześnie za Maghrebińczyka (co nie jest obywatelstwem) i obywatela francuskiego” ${ }^{21}$. Zaraz potem zastrzega: „Być Franko-maghrebińczykiem, być nim 'jak ja', nie oznacza - nie oznacza przede wszystkim, nie oznacza zwłaszcza - jakiegoś nadmiaru lub bogactwa tożsamości, atrybutów czy nazw. Odsłaniałoby to raczej, najpierw, pewne zaburzenie tożsamości"22. Zaburzenie to wiąże się z pojęciem obywatelstwa, które wprawdzie „nie określa uczestnictwa kulturowego, językowego czy historycznego w ogóle [...] nie jest to wszakże powierzchowny lub nadbudowany predykat unoszący się na powierzchni doświadczenia. Zwłaszcza gdy owo obywatelstwo jest na wskroś n i e trwałe, św i eż e, z a g r o ż o n e, bardziej sztuczne niż kiedykolwiek; to właśnie 'mój przypadek', sytuacja zarazem typowa i szczególna"23.

Jest to oczywiście aluzja do polityki władz Vichy wobec Żydów ${ }^{24}$. Wspominając odebranie żydowskim dzieciom prawa do korzystania ze szkół publicznych, Derrida pisze, że „z Liceum Ben Aknoun wyrzucono małego, czarnego, bardzo arabskiego Żyda, który nic nie rozumiał, któremu nikt nigdy tego nie wyjaśnił, ani rodzice, ani przyjaciele"25. Stosunkowo krótkotrwały epizod (Derrida został usunięty ze szkoły w 1942 roku, a przywrócony w 1943) okazał się ważący na stosunku do państwa francuskiego. Biorąc pod uwagę znaczenie, jakie w Europie zwykło się wiązać ze słowem „okupacja” w kontekście II wojny światowej, Derrida podkreśla, że naprawdę Algieria nigdy nie była okupowana, albo raczej - jak precyzuje - ,jeśli kiedykolwiek była okupowana, to z pewnością nie przez okupanta niemieckiego" ${ }^{26}$. Zatem „odebranie obywatelstwa francuskiego Żydom algierskim wraz ze wszystkim, co po tym nastąpiło, było dziełem samych Francuzów. Postanowili o tym zupełnie sami, we własnych głowach, musieli nad tym przemyśliwać od zawsze i zupełnie sami wprowadzili to w czyn"27.

Wspomnienie tego niezrozumiałego dla dziecka wydarzenia pojawia się w książkach i wywiadach wielokrotnie jako dowód nietrwałego charakteru oby-

\footnotetext{
21 J. Derrida, Jednojęzyczność innego..., dz. cyt., s. 37.

22 Tamże, s. 38.

23 Tamże, s. 39.

24 Por.:R. Ayoun, Les Juifs d'Algérie dans la tourmente antisémite du XX $X^{e}$ siècle, „Revue Européenne des Études Hébraïques" 1996, nr 1.

25 G. Bennington, J. Derrida, Jacques Derrida, przeł. V. Szydłowska-Hmissi, Genesis, Warszawa 2009, s. 51.

26 J. Derrida, Jednojęzyczność innego..., dz. cyt., s. 40.

27 Tamże, s. 40.
} 
watelstwa ${ }^{28}$. Doświadczeniu bycia wykluczonym odpowiadają w późniejszych latach życia pełne emocjonalnego zaangażowania wystąpienia publiczne w kontekście kryzysu imigracyjnego we Francji w 1996 roku czy stosowania kary śmierci ${ }^{29}$ w Stanach Zjednoczonych przede wszystkim w stosunku do Afroamerykanów. Algierskie pochodzenie i związane z nim traumy czynią go szczególnie wyczulonym na dramatyczne doświadczenia historyczne innych narodów. W wykładzie wygłoszonym w 1998 roku na Uniwersytecie Śląskim z okazji przyznania mu przez tę uczelnię doktoratu honoris causa, odnosząc się do dwudziestowiecznej historii Polski i podkreślając jej tragiczny charakter, Derrida przypomina o swoim kulturowym i politycznym statusie jako podmiotu zabierającego głos: „... jestem obywatelem francuskim urodzonym w Algierii, tej innej scenie politycznej rozpaczy i historycznej tragedii, tej od dziesięcioleci otwartej ranie"30.

Algier w czasach, kiedy było już dla wszystkich jasne, że rządy Vichy nie potrwają długo - z racji tego, że znajdował się z dala od działań wojennych i nie był miejscem stacjonowania wojsk niemieckich - stał się na krótko stolicą francuskiej kultury wysokiej na wygnaniu ${ }^{31}$. Rozkwitało tu życie literackie i teatralne, powstawały nowe wydawnictwa. Okoliczność ta wzmagała zainteresowanie młodego Derridy obcą, a zarazem coraz bardziej swoją kulturą, przyczyniając się do „bezprecedensowej asymilacji: głębokiej, szybkiej, gorliwej, spektakularnej”32, niebędącej jednak nabyciem spójnej, niepodzielnej tożsamości.

Na szczególną uwagę zasługuje tu język, za pomocą którego Derrida opowiada o tym procesie, zwłaszcza nieprzypadkowy dobór środków stylistycznych we fragmencie, który można uznać za kluczowy do zrozumienia formowanie się jego nietożsamości: „...zostałem jakby przeszyty francuską literaturą i francuską filozofią, jedną i drugą, jedną bądź drugą: były to strzały z metalu

28 Por. J. Derrida, Carte postale de Socrate à Freud et au-delà, Flammarion, Paris 1980, s. 97; tenże, Inny kurs, przeł. T. Załuski, Wydawnictwo Naukowe PWN, Warszawa 2017, s. 13-14.

29 Derrida często wypowiadał się na temat kary śmierci; por. tenże, Glas, Galilée, Paris 1974; tenże, Demeure. Maurice Blanchot, Galilée, Paris 1998; tenże, Donner la mort, Galilée, Paris 1999 (Darować śmierć. Komu darować (Wiedzieć, by nie wiedzieć), przeł. K. Liszka, M. Pawlikowska, w: Czytanie Derridy, red. B. Małczyński, R. Włodarczyk, Uniwersytet Wrocławski, Wrocław 2005); J. Derrida, E. Roudinesco, Z czego jutro... Dialog, przeł. W. Szydłowska, Wydawnictwo Naukowe Scholar, Warszawa 2016.

30 Wykład Jacques’a Derridy (wygłoszony 11 grudnia 1997 roku na Uniwersytecie Śląskim z okazji przyznania mu doktoratu honoris causa), przeł. K. Jarosz, „Literatura na Świecie” 1998, nr 11/12, s. 238.

31 Por. S. Guemriche, Alger la Blanche: biographies d'une ville, Perrin, Lonrai 2012, s. 60-63.

32 J. Derrida, Jednojęzyczność innego..., dz. cyt., s. 42. 
lub z drewna, cząstki, które przenikały wraz ze słowami upragnionymi, odstraszającymi, niedostępnymi nawet wtedy, gdy we mnie wchodziły, zdania, które trzeba było jednocześnie przywłaszczyć sobie, oswoić, pozyskać, czyli pokochać niecąc ogień, podpalić (obraz huby jest zawsze gdzieś niedaleko), być może zniszczyć, a w każdym razie naznaczyć, przekształcić, pociąć, naciąć, wykuć, dotknąć płomieniem, sprawić, by przyszły do mnie w inny sposób, czyli inaczej mówiąc: zarazem do mnie i same w sobie" ${ }^{33}$. Metafory, którymi się posługuje, wskazują na dynamiczny, wręcz destrukcyjny charakter tej relacji. Przywołują one obraz podboju - mowa tu jest przemocy kultury kolonizatora, która nie potrzebuje aktu woli podmiotu, jego intencjonalnego otwarcia. Kultura francuska wnika do jego wnętrza na podobieństwo wystrzelonego pocisku. Derrida opisuje tu kolejny etap kolonizacji „ja”, dla której grunt przygotowały wcześniej instytucje państwa, jego kulturowe i polityczne ekspozytury, zwłaszcza szkoła. W innym miejscu, choć w podobnym kontekście, autor wskazuje na to, że „kultura” i „kolonizacja” pochodzą od tego samego łacińskiego słowa (colo, colere), a zatem „mają wspólne korzenie tam, gdzie chodzi właśnie o to, co przydarza się korzeniom"34.

Nie sposób nie zauważyć, że dynamika dokonującej się w warunkach kolonialnych asymilacji, o której tak efektownie pisze Derrida, jest dwukierunkowa. Podmiot poddany silnej presji przemocy symbolicznej nie może pozostać bezczynny - zagarnia i przekształca, przy czym każde przekształcenie w jakimś stopniu jest niszczeniem, ale też nie jest niszczeniem po prostu. Kulturę francuską - zarazem umiłowaną i niezaprzeczalnie obcą, będącą źródłem rozkoszy i bólu - należy, powtórzmy, „naznaczyć, przekształcić, pociąć, naciąć, wykuć, dotknąć płomieniem". Ta postawa jest skutkiem doświadczenia podmiotu kształtującego się w warunkach pogranicza, a więc przestrzeni kulturowej i politycznej, której właściwe są relacje dominacji i podporządkowania oraz wielorako manifestująca się przemoc, w tym przemoc symboliczna.

Derrida rozpoznający w sobie „rozpęknięcie”, „niepoliczalną, wewnętrzną wielość" ${ }^{35}$, wskazuje, że wynikająca stąd jego „nietożsamość”, „wykorzeniający podział" wiąże się nie tylko z cierpieniem, ale również ze zdolnością krytycznego osądu „dogmatycznych snów” wspólnot, do których jest przyporządkowywany i wobec których pragnie zachować postawę uważności. W rozmowie z Elisabeth

\footnotetext{
33 Tamże, s. 74-75.

34 J. Derrida, Inny kurs, dz. cyt., s. 13-14.

35 J. Derrida, E. Roudinesco, $Z$ czego jutro..., dz. cyt., s. 159.
} 
Roudinesco mówi: „Nie jestem sam ze sobą, nie bardziej niż inny, nie jestem jednym. 'Ja' nie jest niepodzielnym atomem" ${ }^{36}$. Ten nieusuwalny podział wiąże się z cierpieniem (tripalium), ale też jest tym, co skłania do pracy (travail) i jej rezultatom nadaje taki, a nie inny kształt. Tak rozumiane wykorzenienie jest wręcz czymś pożądanym, ponieważ wyzwala, umożliwiając bardziej zdystansowany, bardziej bezstronny osąd polityki różnych wspólnotowych tożsamości.

Swoje zadomowienie w języku francuskim Derrida opisuje jako sytuację, gdy język innego „to jedyny język, którym się mówi, i którym się mówi z jednojęzycznym uporem, w sposób zazdrośnie i surowo idiomatyczny, choć nie jest się $\mathrm{w}$ nim nigdy naprawdę u siebie" ${ }^{37}$. To zadomowienie, bycie u siebie, jest jednak niepełne, ponieważ język ten - choć „najintymniej” zamieszkiwany - ostatecznie okazuje się „niemieszkalny”38. Derrida porównuje go do pustyni, którą dopiero należy obsadzić i zabudować, a następnie wyznaczyć na niej projekty dróg i tras powrotnych - reguły powtórzeń, powrotów i odwracalności. Zgłębiany, przetwarzany i wynajdowany na nowo język nie przestaje przez to być językiem innego. Zamieszkanie w języku francuskim jest możliwe tylko dzięki różnicy, jaką ustanawia wygnanie i nostalgia - „nostalgieria” ${ }^{9}$.

Francuską i - szerzej - zachodnią literaturę oraz filozofię Derrida poznaje zatem w języku, który traktuje jako język innego, a więc pełen nieoczywistości zachęcających do stawiania pytań o pojęcia i relacje między nimi. Swoją postawę wobec zachodniej metafizyki ukazuje jako konsekwencję właśnie tego, ukształtowanego na południowych peryferiach „cywilizacji” stosunku do języka francuskiego: „Wszystkie te słowa: prawda, alienacja, przywłaszczenie, 'u-siebie’, tożsamość, miejsce osoby, prawo itd., pozostają w moich oczach problematyczne. Bez wyjątku. Noszą piętno metafizyki, która wtargnęła właśnie poprzez ten język innego, tę jednojęzyczność innego. Tym samym ów spór z jednojęzycznością nie

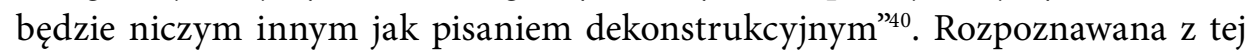
perspektywy problematyczność pojęć tworzących francuskość nie oznacza, że owa francuskość jest w jakiś sposób kaleka - przeciwnie Derrida zdaje się na własnym przykładzie dowodzić tego, że przyswojenie kultury metropolii, gorliwe, a zarazem takie, które nie zaciera całkowicie śladów obcości, pozwala tej

\footnotetext{
36 Tamże, s. 158.

37 J. Derrida, Jednojęzyczność innego..., dz. cyt., s. 89.

38 Tamże, s. 93.

39 Tamże, s. 76.

40 Tamże, s. 96.
} 
kulturze stawiać pytania, których nie postawiłoby się z punktu widzenia pełnego w niej zadomowienia. W świetle jego słów dekonstrukcja nie jest po prostu jeszcze jedną koncepcją filozoficzną, lecz strategicznym działaniem, którego logika, założenia i cele ukształtowały się w kontekście bardzo szczególnego doświadczenia „nietożsamości”.

\section{Widmo Francji}

Derrida dorastał wśród widm. Niczym głos widma z odległej przeszłości docierało do niego echo jego sefardyjskiego pochodzenia, widmowy charakter miała też Francja - jako kraj, język i kultura. Przywołując wspomnienia doświadczeń szkolnych jako ważnych dla kształtowania się jego franko-maghrebińskiej „nietożsamości”, Derrida podkreśla szczególną rolę niepisanych i nieartykułowanych wprost regulacji dotyczących języka, a właściwie języków. Nauka arabskiego w algierskiej szkole była wówczas fakultatywna i traktowano ją tak samo jak naukę na przykład hiszpańskiego czy angielskiego. Język arabski, którym (obok nieobecnego w nauczaniu szkolnym berberyjskiego) mówiono na ulicach, był zatem językiem obcym. Tymczasem francuski był „językiem pana”, „modelem

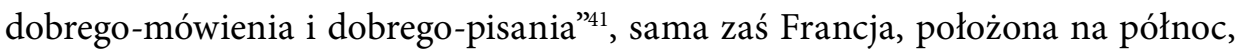
po drugiej stronie morza, częściej nazywana Metropolią niż Francją, jawiła się jako „Miasto-Stolica-Matka-Ojczyzna, civitas języka ojczystego” ${ }^{42}$. Przedmiot nazywany historią Francji był - jak wspomina Derrida - „rodzajem bajki i biblii, ale też doktryną niosącą indoktrynację prawie niemożliwą do zatarcia"*3. Formowana w szkole wyobraźnia geograficzna odnosiła się do tego, co znajdowało się daleko na północ, poza zasięgiem wzroku: „ani słowa o Algierii, ani jednego słowa o jej historii i geografii, podczas gdy mogliśmy rysować z zamkniętymi oczyma wybrzeża Bretanii czy ujście Żyrondy"44. Francja to kraj marzeń, ani obcy, ani swój, daleki, ale w sposób trudny do obiektywizacji, źródło niekwestionowanych dystynkcji i reguł retorycznej elegancji - prototyp widmowości [podkr. R.Ch.]. Jakkolwiek Francja była Metropolią, Algieria nie była przez to prowincją, lecz krajem, choć „w chwiejnym znaczeniu tego słowa, nie tożsamym ani z państwem,

${ }_{41} \quad$ J. Derrida, Jednojęzyczność innego..., dz. cyt., s. 67.

42 Tamże, s. 66.

43 Tamże, s. 68.

44 Tamże, s. 68. 
ani z narodem, ani z religią, ani nawet [...] z autentyczną wspólnotą"45, krajem, w którym odtwarzało się widmowe odbicie relacji stolica/prowincja.

To podwójne oddzielenie - od arabskiego i od francuskiego - Derrida nazywa zakazami, przy czym nie chodzi tu o zakazy formalne; nikt nie zabraniał nikomu uczyć się arabskiego, a nauka francuskiego była tak oczywista, że w ogóle nie trzeba było o niej mówić jak o obowiązku. Autor przywołuje również swoje oddzielenie od tradycji żydowskiej, która była mu obca w inny sposób; algierscy Żydzi nie posługiwali się językiem ladino, który mógłby zapewnić im poczucie odrębności wobec języka kultury oficjalnej. Pisząc o zakazie dotyczącym języka arabskiego, Derrida ma na myśli to, że szkoła w pewien nieformalny, nie zawsze łatwo uchwytny sposób „wykluczała wszelkie odniesienie, [...] wszelką aluzję do Algierii i języka arabskiego" ${ }^{46}$ i zachęcała do wykluczania samych Algierczyków. „To, co mówię, ten, kim mówię, słowem, to ja, o którym mówię, jest kimś - jak mniej więcej pamiętam - komu dostęp do wszelkiego niefrancuskiego języka Algierii (dialektalnego lub literackiego arabskiego, berberyjskiego itd.) był zakazany. Ale to samo ja jest też kimś, komu dostęp do języka francuskiego, choć w inny sposób - na pozór pośredni i pokrętny - również był zakazany. W inny sposób, ale także zakazany. Na mocy zakazu zakazującego jednocześnie dostępu do utożsamień, które pozwalają na uspokojoną autobiografię, na 'pamiętniki' w klasycznym znaczeniu. W jakim języku pisać pamiętniki, kiedy nie było dozwolonego języka ojczystego? Jak powiedzieć jakiekolwiek istotne 'przypominam sobie', kiedy trzeba wymyślać i swój język, i swoje ja, wymyślać je równocześnie, ponad owym wylewem amnezji, rozpętanym przez podwójny zakaz?"47.

Francuski dla Derridy jest jedynym językiem, w którym czuje się bezpiecznie, jakkolwiek pozostaje on językiem innego. Przyznaje, że w istocie nie posiada języka ojczystego, a francuski jest jedynie jego substytutem. Zauważa, że możliwy do usłyszenia w mowie algierski akcent jest „nie do pogodzenia $z$ intelektualną godnością słowa publicznego"48; wyraża przy tym nadzieję, że w żadnej jego publikacji nie będzie śladów owej algierskości. „Nie sądzę - przynajmniej na razie i póki ktoś nie wykaże, że jest inaczej - aby można było wykryć w lekturze, i jeśli sam tego nie obwieszczę, że jestem 'algierskim Francuzem'”49.

\footnotetext{
45 Tamże, s. 67.

46 J. Derrida, E. Roudinesco, $Z$ czego jutro..., dz. cyt., s. 156.

47 Tamże, s. 55.

48 J. Derrida, Jednojęzyczność innego..., dz. cyt., s. 70.

49 Tamże, s. 70.
} 


\section{Przemoc białej mitologii}

Niepełne zadomowienie w języku pozwala traktować go jako nieprzezroczysty i problematyczny, stawiać pytanie o to, co robi on z tymi, którzy się za jego pomocą wypowiadają. Prowadzone przez Derridę analizy tekstów filozoficznych, począwszy od pism Edmunda Husserla, pokazują, mówiąc najogólniej, że język zmusza nas do myślenia w pewien sposób. Tak sformułowany pogląd Derrida podziela $\mathrm{z}$ etnolingwistyką i niektórymi nurtami antropologii kultury. Jego uwaga koncentruje się jednak na języku metafizyki, przy czym - jak zauważa Gayatri Chakravorty Spivak we wprowadzeniu do swojego przekładu bodajże najbardziej znanej książki Derridy - termin "metafizyka” jest tu stosowany jako nazwa wszelkiej nauki o obecności ${ }^{50}$. To właśnie „bycie jako obecność” jest - jak pisze autor Głosu i fenomenu - „wspólną matrycą” takich pojęć jak sens, idealność, obiektywność, prawda czy naocznośćs1.

Niezwykłość krytycznej, antymetafizycznej strategii Derridy polega na sprawianiu, że to sam język metafizyki ujawnia, do jakiego myślenia nas zmusza ${ }^{52}$. Komentując Wprowadzenie do metafizyki Heideggera, stwierdza: „Zachodnia metafizyka, rozumiana jako ograniczenie sensu bycia do obszaru obecności, wytwarza się jako dominacja pewnej formy językowej. Badanie źródła tej dominacji nie sprowadza się do hipostazowania znaczonego transcendentalnego, lecz do stawiania pytań o to, co konstytuuje naszą historię, oraz o to, co wytworzyło samą transcendentalność"

$\mathrm{Z}$ tego punktu widzenia krytyka logocentryzmu jest krytyką przekonania o tym, że świat jest logicznie ustrukturyzowaną całością, którą można w pełni adekwatnie opisać za pomocą języka. Kwestia ta pojawiła się już w słynnym referacie pt. Struktura, znak i gra $w$ dyskursie nauk humanistycznych wygłoszonym w 1966 roku na konferencji zorganizowanej przez Uniwersytet Johna Hopkinsa w Baltimore ${ }^{54}$. Powołując się na Fryderyka Nietzschego, Derrida stwierdzał tam,

50 Por. G. Ch. Spivak, Translator's Preface, w: J. Derrida, Grammatology, przeł. G. Ch. Spivak, The John Hopkins University Press, Baltimore-London 1997, s. XXI.

51 J. Derrida, Głos i fenomen. Wprowadzenie do problematyki znaku w fenomenologii Husserla, przeł. B. Banasiak, KR, Warszawa 1997, 167.

52 Por. W. Lorenc, Hegel i Derrida..., dz. cyt., s. 213.

53 J. Derrida, O gramatologii, dz. cyt., s. 45.

54 Por. J. Derrida, Struktura, znak i gra $w$ dyskursie nauk humanistycznych, przeł. M. Adamczyk, „Pamiętnik Literacki” 1986, nr LXXVII. 
że zachodnia metafizyka oparta jest na złudzeniu uniwersalności prawdy i sensu, tymczasem ma ona lokalny charakter. Europocentryczne roszczenia do uniwersalności jego zdaniem najlepiej obnaża etnologia. Claude’owi Lévi-Straussowi przypisuje Derrida także podważenie niektórych kluczowych dla zachodnioeuropejskiej metafizyki opozycji, zwłaszcza przeciwstawienia natury i kultury. Zdaniem autora Smutku tropików nadrzędnym zadaniem antropologii kultury było projektowanie na innego przekonań, które trudno byłoby pogodzić z właściwą „cywilizacji” ideą braku ciągłości między tym, co ludzkie, i tym, co zwierzęce ${ }^{55}$.

Późniejsze prace Derridy przyniosły - jak pamiętamy - gruntowną krytykę leżącego u podstaw antropologii strukturalnej przekonania, że istnieje obiektywny punkt widzenia, z którego można prawomocnie badać reprezentacje. Komentując myśl autora Gorączki archiwum, Vincent Descombes rozważa możliwość fenomenologii historii i przy tej okazji testuje możliwość pojęcia prawdy w mocnym sensie tego słowa, prawdy absolutnej, a więc nie prawdy „dla nas”, ponieważ „dla nas” pojęcie to jest czymś więcej niż prawda „dla nas”. Prawda obiektywna, niezależna od uwikłanego w przygodność punktu widzenia jest dostępna pod warunkiem bycia Bogiem, a ci, którzy nim nie są, muszą pogodzić się z tym, że ich prawdy to tylko „perspektywy” czy „wartości” ${ }^{\text {. }}$

W tej optyce cała zachodnia metafizyka jest logocentryczna, tzn. oparta na przekonaniu, że istnieje obiektywna prawda i niepodważalne kryteria, na podstawie których można oddzielić to, co prawdziwe, od tego, co fałszywe. Logocentryzm jest „etnocentryczną metafizyką" i jako taki jest związany $\mathrm{z}$ historią Zachodu, $\mathrm{w}$ tym $\mathrm{z}$ historią jego dominacji ${ }^{57}$. W innym miejscu, na marginesie komentarza do Ogrodu Epikura Anatola France’a, czytamy, że ta metafizyka to „biała mitologia, która skupia w sobie i odzwierciedla kulturę Zachodu: biały człowiek traktuje swoją mitologię - indoeuropejską - swój logos, czyli mythos swego idiomu, jako formę uniwersalną tego, co zapewne jeszcze chce nazywać Rozumem"58. Derrida podziela pogląd Lévinasa o fundamentalnym związ-

55 Por. R. Chymkowski, Zwierzęta i antropologia kultury, „Przegląd Humanistyczny” 2014, nr 1, s. 36.

56 V. Descombes, To samo i inne. Czterdzieści pięć lat filozofii francuskiej (1933-1978), przeł. B. Banasiak, K. Matuszewski, Wydawnictwo Spacja, Warszawa 1996, s. 170-173.

57 Por. J. Derrida, O gramatologii, dz. cyt., s. 118.

58 J. Derrida, Marginesy filozofii, przeł. A. Dziadek, J. Margański, P. Pieniążek, Wydawnictwo KR, Warszawa 2002, s. 266. 
ku zachodniego logosu z przemocą ${ }^{59}$. Temat ten powraca w różnych odsłonach w wielu książkach, m.in. w Gorączce archiwum: „Odkąd istnieje Jeden, istnieje zabójstwo, zranienie, trauma. L'Un se garde de l'autre. Jeden wystrzega się/strzeże innego. Strzeże się przed innym, lecz w ruchu tej zazdrosnej przemocy, niesie, a zatem zachowuje inność czy różnicę 'w sobie' (różnicę wynikającą ' $z$ siebie'), które powodują, że staje się Jednym. 'Jeden odróżnia się od samego siebie’. Jeden jako Inny. Zarazem i równocześnie, lecz w rozłącznych czasach, Jeden zapomina przypomnieć się sobie, zachowuje i zaciera tę niesprawiedliwość, którą sam jest. Tę przemoc, którą sam wytwarza. L'Un se fait violence. Jeden dopuszcza się przemocy. Dopuszcza się gwałtu i sam staje się przemocą, lecz również ustanawia się jako przemoc"60.

Krytyka zachodniego logocentryzmu jest jednym z powodów, dla których Derrida jest stale obecny w pismach myślicieli z kręgu studiów postkolonialnych i postzależnościowych. W artykule pt. Czy podporządkowani inni moga przemówić? Spivak zauważa: „Niektóre z najbardziej radykalnych dyskursów krytycznych, jakie pojawiły się w latach 80 . na Zachodzie, były rezultatem pragnienia zainteresowanego tym, by utrwalić podmiot Zachodu czy też Zachód jako Podmiot. Teoria zwielokrotnionych efektów podmiotu często zapewniała osłonę dla tego podmiotu wiedzy. Choć historia Europy jako podmiotu była narratywizowana przez prawo, ekonomię politykę i ideologię Zachodu, ów zamaskowany

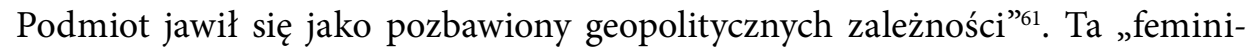
styczno-marksistowska dekonstrukcjonistka" ${ }^{62}$ podkreśla przy tym, że w odróżnieniu od Michela Foucaulta, którego aparat pojęciowy umożliwił Saidowi napisanie Orientalizmu, Derrida był „świadomy etnocentryzmu produkcji wiedzy od samego początku swojej twórczości” ${ }^{63}$.

59 Por. W. Lorenc, Hegel i Derrida. Filozofia w wersji radykalnej, Instytut Filozofii UW, Warszawa 1994, s. 192.

60 J. Derrida, Goraczka archiwum. Impresja freudowska, przeł. J. Momro, Instytut Badań Literackich PAN, Warszawa 2016, s. 118.

${ }_{61}$ G. Ch. Spivak, Czy podporządkowani inni moga przemówić?, przeł. E. Majewska, „Krytyka Polityczna" 2010, nr 24/25, s. 196.

${ }_{62}$ Por. C. MacCabe, Foreword, w: G. Ch. Spivak, In other words. Essays in Cultural Politics, Methuen, New York-London 1987, s. IX.

63 G. Ch. Spivak, Czy podporządkowani inni moga przemówić?, dz. cyt., s. 218. 


\section{Dekonstrukcja interweniująca}

Problem z polityczną recepcją Derridy jest też taki, że całe życie unikał przynależności do jakiejkolwiek organizacji politycznej i rzadko wypowiadał się na tematy związane z bieżącą polityką. Niektórzy badacze jego dorobku wskazują na to, że na temat polityki czy raczej polityczności zaczął się wypowiadać dopiero od połowy lat 80 . XX w., tymczasem problematyka ta była stale obecna w jego pismach, właściwie od samego początku, choć nie zawsze wprost. Niezależnie od tego, że jego strategia analityczna polegała na bliskiej lekturze tekstów źródłowych, zawsze chodziło o coś więcej - o krytyczny namysł nad ich podstawą pojęciową. Można zatem powiedzieć, że polityczność myśli Derridy, podobnie jak jej etyczny aspekt, jest najpierw negatywna, a potem dopiero pozytywna, negatywność jest warunkiem pojawienia się pozytywności, to znaczy Derrida nie wychodzi od formułowania postulatów politycznych, dla których następnie szukałby uzasadnienia, lecz od krytycznego rozpoznania aporetycznego charakteru metafizycznych aksjomatów, na których zbudowane są systemy dominacji kulturowej, a przez to i politycznej.

Wskazówki dotyczące politycznego zaangażowania prac Derridy nieraz znajdują się na ich marginesach albo wręcz ukryte są w ich kontekście. Przykładowo - Widma Marksa, prawdopodobnie najbardziej bezpośrednio polityczna spośród książek Derridy, powstała tuż po obaleniu Muru Berlińskiego, trzy lata po śmierci urodzonego również w Algierii Louisa Althussera, którego Derrida poznał podczas studiów w École normale supérieure (ENS). Deklaracją światopoglądową, ale też polityczną, jest dedykacja tej książki Chrisowi Haniemu, znanemu z walki $\mathrm{z}$ apartheidem liderowi południowoafrykańskiej partii komunistycznej, zamorodowanemu przez pochodzącego z Polski Janusza Walusia.

Zainteresowanie Derridy Marksem sięga wstecz przynajmniej równie głęboko jak znajomość z Althusserem. Warto jednak zwrócić uwagę także na te jego wypowiedzi, w których opisuje dekonstrukcję jako krytykę historii rozumianej jako historia sensu, historii logocentrycznej i idealistycznej, krytykę transcendentalnego signifié, przy tej bowiem okazji Derrida sygnalizuje własne swoiście pojęte stanowisko materialistyczne. W jednym z wywiadów wspomina o swoim zainteresowaniu materializmem „mechanistycznym”64. „Bez lektury Marksa - pisze Derrida - nie będzie żadnej przyszłości. [...] w każdym razie bez,

${ }_{64}$ J. Derrida, Pozycje..., dz. cyt., s. 49. 
bez rozumianego w określony sposób Marksa, bez jego geniuszu i jego ducha, bez jednego $\mathrm{z}$ jego duchów"65. Z jednej strony zastrzega, że nie należy interpretacji pism Marksa dopasowywać do potrzeb podyktowanych bieżącymi okolicznościami politycznymi, z drugiej podkreśla, że lektura Marksa, jak każda inna lektura, musi być przekształcaniem (słychać tu echo prac Althussera), a marksizm jest jednocześnie niezbędny i niewystarczający. Czytanie Marksa w duchu Marksa powinno zatem uwzględnić nowe uwarunkowania ideologiczne, widma religijne, nieznane autorowi Kapitału technologie produkcyjne i komunikacyjne, a także uzależnienie państw od kapitału, a właściwie od różnych kapitałów - ekonomicznych i symbolicznych, państwowych i prywatnych, zawsze powiązanych $\mathrm{z}$ widmowymi siłami ${ }^{66}$.

Pewne tematy polityczne w twórczości Derridy powracają szczególnie często. Należy do nich kwestia antysemityzmu, na który autor Marginesów filozofii jest wyczulony od czasów swojego algierskiego dzieciństwa. W latach 90. często zwraca uwagę na nieoczekiwany powrót tych demonów przeszłości w środowiskach i miejscach, o których dotychczas można było myśleć, że są przed nimi trwale zabezpieczone. $\mathrm{Z}$ drugiej strony podkreśla pozytywną zmianę we francuskiej polityce historycznej, której świadectwem jest to, że prezydent Jacques Chirac publicznie przeprosił za nienaprawialne krzywdy wyrządzone Żydom przez Państwo Francuskie (tj. Francję Vichy). Przerwanie dziejów Republiki i ustanowienie Państwa Francuskiego dokonało się zgodnie z prawem, za pośrednictwem legalnie wybranych przedstawicieli narodu. Podczas wykładu w warszawskiej Zachęcie Derrida powiedział m.in.: „To, że przez pół wieku, żaden francuski mąż stanu nie uznał, za możliwe, pożyteczne, konieczne czy słuszne, by ustalić prawdę dotyczącą wielkiej francuskiej winy, uznać tę winę za prawdę, daje do pomyślenia, porusza i wywołuje drżenie"67.

Derrida wskazuje negatywne skutki uboczne współczesnego antysemityzmu dla języka debaty publicznej; jego zdaniem symptomem tej choroby jest wahanie, które odczuwamy, kiedy chcemy potępić instrumentalizację pamięci o Holokauście albo skrytykować politykę Izraela, tudzież jakiejś żydowskiej zbiorowości. Potępiając antysemityzm, zarazem nie chce być Żydem definiowanym jako czło-

65 J. Derrida, Widma Marksa. Stan dtugu, praca i nowa Międzynarodówka, przeł. T. Załuski, Wydawnictwo Naukowe PWN, Warszawa 2016, s. 36.

66 Por. tamże, s. 105.

67 J. Derrida, Historia kłamstwa. Prolegomena. Wykład warszawski, przeł. V. Hmissi, Wydawnictwo IFiS PAN, Warszawa 2005, s. 39. 
nek pewnej „zintegrowanej” mniejszości, ponieważ taka identyfikacja jest symetryczną odwrotnością wypędzenia, o czym przypomina mu doświadczenie algierskie. Drugi powód tej niechęci ma charakter bardziej ogólny i wiąże się $\mathrm{z}$ niepokojem wywoływanym pojęciem tożsamości ${ }^{68}, \mathrm{w}$ tym tożsamości zbiorowej wyobrażonej wspólnoty. W jednym $\mathrm{z}$ filmów biograficznych stwierdza, że „my” jest „obietnicą, żądaniem, nadzieją, to także strach. [...] Kiedy mówię 'my', mam nadzieję, że to nie my, że nie jesteśmy zamknięci wewnątrz tego 'my"'69.

Krytyka założeń metafizycznych tkwiących u podstaw pewnego ruchu politycznego nie wyklucza, przynajmniej w perspektywie doraźnej, postawy pragmatycznej. Derrida wielokrotnie wyraża zaniepokojenie logiką czy „popędem” tożsamości nie tylko w komunitarianizmie, ale także w „narcyzmie mniejszości” charakterystycznym m.in. dla feminizmu czy autoafirmatywnych mniejszości etnicznych. Rozpoznanie to nie zwalnia jednak z politycznej odpowiedzialności, z obowiązku solidarności z walczącymi przeciwko takiej czy innej formie systemowej dyskryminacji lub opresji, domagającymi się uznania pewnej, nomen omen, tożsamości narodowej, religijnej czy językowej ${ }^{70}$. Względy pragmatyczne każą tymczasowo zawieszać krytykę, a z drugiej strony przypominają o tym, że zawierając sojusze polityczne, należy mieć na uwadze ich granice temporalne i przestrzenne. Zabierając głos w sprawie wpisania do konstytucji parytetu płci w życiu publicznym, zaznacza, że podniesienie binarnej opozycji płci biologicznej do rangi konstytucyjnej budzi jego niepokój, niemniej w konkretnej sytuacji, kiedy można tylko głosować za albo przeciw, poparłby to rozwiązanie, ponieważ zdaje sobie sprawę, że pod tym względem „Francja jest krajem najbardziej zacofanym w Europie"71.

Pisząc i mówiąc o potrzebie nowej filozofii polityki, Derrida zwraca uwagę na konieczność redefinicji takich pojęć jak wspólnota i wolność. Jego zdaniem należy dokonać podwójnego wyzwolenia - po pierwsze wyzwolić język polityczności ze słownika komunitarianizmu, a więc przemyśleć pojęcie wspólnoty w języku różnicy i wielości (inny nie jest iteracją ja) ${ }^{72}$, nie zaś jedności i tożsamości, a po

68 Por. D. Bachamann-Medick, Cultural Turns. Nowe kierunki w naukach o kulturze, przeł. K. Krzemieniowa, Oficyna Naukowa, Warszawa 2012, s. 223.

69 Derrida, reż. K. Dick, A. Ziering Kofman, 2002.

70 Por. J. Derrida, E. Roudinesco, $Z$ czego jutro..., dz. cyt., s. 37.

71 Tamże, s. 39.

72 Derrida podziela pogląd Arendt o tym, że u podstaw wszelkiej polityczności znajduje się „fakt ludzkiej wielości”. (Por. H. Arendt, Wprowadzenie w politykę, w: tejże, Polityka jako obietnica, przeł. W. Madej, M. Godyń, opr. i wstęp: J. Kohn, posł. P. Nowak, Prószyński i S-ka, Warszawa 
drugie wyzwolić pojęcie wolności ze słownika liberalizmu, to znaczy przemyśleć wolność jako wspólnotę wolnych namiętności, a nie przywilej nielicznych, tudzież prawo do posiadania.

\section{Dekonstrukcja jako dekolonizacja}

Niezależnie od tego, że polityczność myśli Derridy była stawiana pod znakiem zapytania, istnieje bardzo żywy nurt recepcji na gruncie szeroko rozumianych studiów postkolonialnych, w którym istotną rolę odgrywa świadomość biograficznych związków autora Marginesów filozofii z kolonialną Algierią ${ }^{73}$. Podsumowując tę bogatą twórczość, Omar Boussaha stwierdza: „Poprzez dekonstrukcję europocentryzmu i szerzej pojętego okcydentalocentryzmu Jacques Derrida rozumiał poddanie krytyce globalnego systemu dominacji" ${ }^{74}$. W podobnym tonie wypowiada się Leela Gandhi, podkreślając, że dzięki jego pracom możemy dziś „diagnozować materialne skutki i implikacje kolonializmu jako epistemologicznej choroby w samym sercu zachodniego racjonalizmu"75. Z tego punktu widzenia najpowszechniej znany pomysł Derridy - dekonstrukcja - wydaje się przede wszystkim „formą kulturowej i intelektualnej dekolonizacji”76, tym, co pozwala, jak to zgrabnie ujął Mamadou Diouf, „wyjść z biblioteki kolonialnej”77.

$\mathrm{Na}$ ostatnich stronach tekstu o jednojęzyczności innego Derrida wprost pisze o pierwszorzędnej roli algierskiego epizodu swojej biografii w uformowaniu tej szczególnej formy postawy krytycznej, którą łączymy przede wszystkim z pojęciem dekonstrukcji: „Judeo-franko-maghrebińska genealogia nie wyjaśnia wszystkiego, z pewnością nie. Lecz czy mógłbym wyjaśnić coś bez niej, kiedy-

2005, s. 124).

73 Por. A. Moghith, Le politique dans les textes. Jacques Derrida entre éthique et politique, w: Derrida à Alger. Un regard sur le monde, red. M. Chérif, Actes Sud, Barzakh, Arles-Alger 2008, s. 76.

74 O. Boussaha, La mise à nu des pouvoirs de domination, w: Derrida à Alger..., dz. cyt., s. 115.

75 L. Gandhi, Teoria postkolonialna. Wprowadzenie krytyczne, tłum. J. Serwański, posł.: E. Domańska, Wydawnictwo Poznańskie, Poznań 2008, s. 31.

76 R.J.C. Young, Postcolonialism. An Historical Introduction, Blackwell Publishing, Oxford 2011, s. 421.

77 Por. M. Diouf, Introduction. Entre l'Afrique et l'Inde: sur les questions colonials et nationales. Ecritures de l'histoire et recherches historiques, w: L'historiographie indienne en débat. Colonialisme, nationalisme et sociétés postcoloniales, red. M. Diouf, Éditions Karthala, Sephis, Paris-Amsterdam 1999, s. 29. 
kolwiek? Nie, nic - nic z tego, co mnie zaprząta, angażuje, utrzymuje w ruchu lub w 'komunikacji', nic z tego, co mnie czasem wzywa z głębi milczącego czasu komunikacji przerwanych, nic $\mathrm{z}$ tego również, co mnie izoluje $\mathrm{w}$ jakimś prawie mimowolnym schronieniu, na pustyni, gdzie mam niekiedy złudzenie, że ją sam 'uprawiam', że ją przemierzam jako pustynię, i gdzie dostarczam sobie pięknych i słusznych racji - takich jak zniechęcenie, ale także 'etyka' i 'polityka'! - gdy tymczasem przeznaczono mi miejsce zakładnika, miejsce-zobowiązanie, tuż przede mną" ${ }^{78}$. Badając społeczno-polityczną genezę poststrukturalizmu Robert J.C. Young, przywołuje jego związek z południem; z tego punktu widzenia Derridiańska dekonstrukcja jest „teorią franko-maghrebińską"79.

$\mathrm{Na}$ próżno zapewne byłoby dociekać, które z doświadczeń biograficznych Derridy i w jakim stopniu zainicjowało jego dekonstrukcyjny stosunek wobec wchłanianej wraz z językiem francuskim zachodniej metafizyki; ważniejsze wydaje się dostrzeżenie, że pozornie tekstocentryczna filozofia Jacques’a Derridy nie jest niewinna; wyrastając $z$ konkretnych doświadczeń intelektualisty dojrzewającego na peryferiach jest narzędziem, którym posługuje się on w celu wniknięcia do centrum po to, by je rozsadzić.

\section{Bibliografia}

Arendt H., Wprowadzenie w politykę, w: tejże, Polityka jako obietnica, tłum. W. Madej, M. Godyń, opr. i wstęp: J. Kohn, posł. P. Nowak, Prószyński i S-ka, Warszawa 2005.

Ayoun R., Les Juifs d'Algérie dans la tourmente antisémite du XXe siècle, „Revue Européenne des Études Hébraïques" 1996, nr 1.

Bachamann-Medick D., Cultural Turns. Nowe kierunki w naukach o kulturze, tłum. K. Krzemieniowa, Oficyna Naukowa, Warszawa 2012.

Bennington G., Derrida J., Jacques Derrida, tłum. V. Szydłowska-Hmissi, Genesis, Warszawa 2009.

78 J. Derrida, Jednojęzyczność innego..., dz. cyt., s. 109-110.

79 Por. R.J.C. Young, White Mythologies. Writing History and the West, Routledge, London-New York 2005, s. 7. 
Bielik-Robson A., „Na pustyni”. Kryptoteologie późnej nowoczesności, Universitas, Kraków 2008.

Bourdieu P., Dystynkcja. Społeczna krytyka władzy sądzenia, tłum. P. Biłos, Wydawnictwo Naukowe Scholar, Warszawa 2005.

Boussaha O., La mise à nu des pouvoirs de domination, w: Derrida à Alger. Un regard sur le monde, red. M. Chérif, Actes Sud, Barzakh, Arles-Alger 2008.

Chérif M., L'Islam et l'Occident. Rencontre avec Jacques Derrida, Odile Jacob, Paris 2006.

Chymkowski R., Zwierzęta i antropologia kultury, „Przegląd Humanistyczny” 2014, nr 1.

Derrida J., Carte postale de Socrate à Freud et au-delà, Flammarion, Paris 1980.

Derrida J., Darować śmierć. Komu darować (Wiedzieć, by nie wiedzieć), tłum. K. Liszka, M. Pawlikowska, w: Czytanie Derridy, red. B. Małczyński, R. Włodarczyk, Uniwersytet Wrocławski, Wrocław 2005.

Derrida J., Demeure. Maurice Blanchot, Galilée, Paris 1998.

Derrida J., Donner la mort, Galilée, Paris 1999.

Derrida J., Glas, Galilée, Paris 1974.

Derrida J., Głos i fenomen. Wprowadzenie do problematyki znaku w fenomenologii Husserla, tłum. B. Banasiak, KR, Warszawa 1997.

Derrida J., Goraczka archiwum. Impresja freudowska, tłum. J. Momro, Instytut Badań Literackich PAN, Warszawa 2016.

Derrida J., Historia kłamstwa. Prolegomena. Wykład warszawski, tłum. V. Hmissi, Wydawnictwo IFiS PAN, Warszawa 2005.

Derrida J., Inny kurs, tłum. T. Załuski, Wydawnictwo Naukowe PWN, Warszawa 2017.

Derrida J., Jednojęzyczność innego czyli proteza oryginalna, tłum. A. Siemek, „Literatura na Świecie" 1998, nr 11-12(328-329).

Derrida J., Marginesy filozofii, tłum. A. Dziadek, J. Margański, P. Pieniążek, Wydawnictwo KR, Warszawa 2002.

Derrida J., O gramatologii, tłum. B. Banasiak, Wydawnictwo KR, Warszawa 1999.

Derrida J., Ostrogi. Style Nietschego, tłum. B. Banasiak, Officyna, Łódź 2012.

Derrida J., Przemoc i metafizyka, w: tegoż, Pismo i różnica, tłum. K. Kłosiński, KR, Warszawa 2004.

Derrida J., Roudinesco E., Z czego jutro... Dialog, tłum. W. Szydłowska, Wydawnictwo Naukowe Scholar, Warszawa 2016. 
Derrida J., Struktura, znak i gra $w$ dyskursie nauk humanistycznych, tłum. M. Adamczyk, „Pamiętnik Literacki” 1986, nr LXXVII.

Derrida J., Widma Marksa. Stan długu, praca i nowa Międzynarodówka, tłum. T. Załuski, PWN, Warszawa 2016.

Descombes V., To samo i inne. Czterdzieści pięć lat filozofii francuskiej (19331978), tłum. B. Banasiak, K. Matuszewski, Wydawnictwo Spacja, Warszawa 1996.

Diouf M., Introduction. Entre l'Afrique et l'Inde: sur les questions colonials et nationales. Ecritures de l'histoire et recherches historiques, w: L'historiographie indienne en débat. Colonialisme, nationalisme et sociétés postcoloniales, red. M. Diouf, Éditions Karthala, Sephis, Paris-Amsterdam 1999.

Gandhi L., Teoria postkolonialna. Wprowadzenie krytyczne, tłum. J. Serwański, posł.: E. Domańska, Wydawnictwo Poznańskie, Poznań 2008.

Guemriche S., Alger la Blanche: biographies d'une ville, Perrin, Lonrai 2012.

Haddour A., Introduction: Remembering Sartre, w: J.-P. Sartre, Colonialism and Neocolonialism, tłum. A. Haddour, S. Brewer, T. McWilliams, Routledge, London-New York 2001.

Heidegger M., Koniec filozofii i zadanie myślenia, tłum. K. Michalski, w: Drogi współczesnej filozofii, wybór i wstęp: M. Siemek, Czytelnik, Warszawa 1978.

Heidegger M., La fin de la philosophie et la tâche de la pensée, tłum. J. Beaufret, F. Fédier, w: Kierkegaard vivant: colloque organisé par l'Unesco à Paris du 21 au 23 avril 1964, Gallimard, Paris 1966.

Khatibi A., La Mémoire tatouée: autobiographie d'un décolonisé, Denoël, Paris 1982.

Le Sueur James D., Uncivil War. Intellectuals and Identity Politics during the Decolonization of Algeria, wstęp: P. Bourdieu, University of Nebraska Press, Lincoln-London 2005.

Leder A., Był kiedyś postmodernizm... Sześć esejów o schyłku XX stulecia, Wydawnictwo IFiS PAN, Warszawa 2018.

Lorenc W., Hegel i Derrida. Filozofia w wersji radykalnej, Instytut Filozofii UW, Warszawa 1994.

Lyotard J.-F., La guerre des Algériens. Écrits 1956-1963, opr. i wstęp: M. Ramdani, Galilée, Paris 1989.

MacCabe C., Foreword, w: G. Ch. Spivak, In other words. Essays in Cultural Politics, Methuen, New York-London 1987. 
Moghith A., Le politique dans les textes. Jacques Derrida entre éthique et politique, w: Derrida à Alger. Un regard sur le monde, red. M. Chérif, Actes Sud, Barzakh, Arles-Alger 2008.

Powell J., Jacques Derrida: A Biography, Continuum, London-New York 2006.

Spivak G.Ch., Translator's Preface, w: J. Derrida, Grammatology, tłum. G.Ch. Spivak, The John Hopkins University Press, Baltimore-London 1997, s. XXI.

Spivak G.Ch., Czy podporzadkowani inni moga przemówić?, tłum. E. Majewska, „Krytyka Polityczna” 2010, nr 24/25.

Wykład Jacques'a Derridy (wygłoszony 11 grudnia 1997 roku na Uniwersytecie Śląsim z okazji przyznania mu doktoratu honoris causa), tłum. K. Jarosz, „Literatura na Świecie" 1998, nr 11/12.

Young R.J.C., Postcolonialism. An Historical Introduction, Blackwell Publishing, Oxford 2011.

Young R.J.C., White Mythologies. Writing History and the West, Routledge, London-New York 2005.

\section{Filmografia}

D’ailleurs, Derrida, reż. S. Fathy, 1999.

Derrida, reż. K. Dick, A. Ziering Kofman, 2002.

\section{Streszczenie}

Posteuropocentryczny i postkolonialny ton prowadzonej przez francuskich intelektualistów krytyki tradycji intelektualnej Zachodu jest genetycznie związany z doświadczeniem dekolonizacji, która była procesem nie tylko politycznym, militarnym i gospodarczym, ale też filozoficznym i światopoglądowym, przy czym te wszystkie jej aspekty były wzajemnie ze sobą splecione. Polemizuję ze stanowiskiem polegającym na traktowaniu kształtującego się wówczas postkolonialnego tonu krytyki nauki europejskiej i leżących u jej podstaw założeń metafizycznych w oderwaniu od doświadczania politycznego aspektu dekolonizacji. Jeśli weźmiemy pod uwagę biografie intelektualistów, którzy odcisnęli największe piętno na humanistyce drugiej połowy XX wieku (np. Jacques’a Derridy), debata ponowoczesności i końcu metafizyki, wbrew utartej interpretacji, mniej 
ma wspólnego z abstrakcyjną krytyką Kartezjańskiego podmiotu niż z realiami politycznymi rozpadu francuskiego imperium kolonialnego, zwłaszcza wojny o niepodległość Algierii. Derrida podkreślający swój hybrydowy status kulturowy wiele uwagi poświęca pogranicznemu charakterowi uprawianej przez siebie filozofii, z nietożsamości czyniąc jeden z jej głównych tematów i znaków rozpoznawczych. Poprzez dekonstrukcję europocentryzmu i szerzej pojętego okcydentalizmu Derrida rozumiał poddanie krytyce globalnego systemu dominacji. Filozofia Derridy wyrastająca z doświadczeń intelektualisty dojrzewającego na peryferiach skolonizowanego świata jest narzędziem, którym posługuje się on w celu pozbawienia w dziełach Derridy, nie zamyka się w obrębie jednej teorii, lecz znajduje się wewnątrz całej współczesnej myśli humanistycznej, nadając jej dynamikę, a zarazem rozsadzając, tzn. nie pozwalając ustanowić trwałej tożsamości. Poszukując w pracach Derridy dróg, którymi może podążać zachodnia myśl krytyczna, natrafiamy na świadectwa tego, że nie jest ona, a może nawet nigdy nie była „zachodnia” w sensie, jaki temu słowu nadaje język tożsamości, i że właśnie jej nietożsamość jest warunkiem pozytywności.

Słowa kluczowe: Derrida, postmodernizm, posteuropocentryzm, postkolonializm, dekolonizacja

\section{Summary}

\section{What Comes After Postmodernism? Derrida and Nonidentity}

Posteuropocentric and postcolonial animus in French intellectuals' criticism of the Western intellectual tradition is genetically tied to the experience of decolonization, which was not just a political, military and economic process, but also one of philosophy and worldview. All those aspects were closely woven together. I am polemical towards the outlook treating the shaping of the then-contemporary postcolonial tone in the criticism of European sciences and their metaphysical grounding in separation with the aspect of the political experience of the decolonization process. If we take under consideration the biographies of intellectuals who have left the biggest mark on the humanities of the second half of the XXth century (e.g. Jacques Derrida), then the debate on post-modernity and 
the end of metaphysics has, in spite of the common view, less to do with abstract criticism of the Cartesian subject than with political realities of the collapse of the French colonial empire, and the Algerian War of Independence in particular. Derrida, who highlighted his hybrid cultural status, gave a lot of attention to the liminal character of his philosophy, making nonidentity one of his main objects of interest. By deconstructing europocentrism and widely-understood occidentalism, Derrida understood criticism of a global system of domination. Derrida's philosophy, stemming from the experiences of an intellectual raised on the periphery of a colonized world is a tool he used to take away from the metropole the metaphysical groundings of the power it held. Anticolonial or postcolonial timbre in analyzed Derrida's works is not limited to a single theory, but is at home at the heart of the entirety of contemporary humanities. It gives it its dynamism, but also blows it up, allowing no stable identity. In searching for ways that Western critical thought can follow after the works of Derrida, we find evidence that it is not, and maybe has never been "Western" in the sense that the language of identity implies, and that it is its nonidentity that makes it positive.

Keywords: Derrida, postmodernism, posteuropocentrism, postcolonialism, decolonization 